\title{
Evolution of the Petal and Stamen Developmental Programs: Evidence from Comparative Studies of the Basal Angiosperms
}

\section{Citation}

Kramer, Elena M. and Vivian F. Irish. 2000. Evolution of the petal and stamen developmental programs: Evidence from comparative studies of the basal angiosperms. International Journal of Plant Science 161(S6): S29-S40.

\section{Published Version}

http://dx.doi.org/10.1086/317576

\section{Permanent link}

http://nrs.harvard.edu/urn-3:HUL.InstRepos:2624676

\section{Terms of Use}

This article was downloaded from Harvard University's DASH repository, and is made available under the terms and conditions applicable to Other Posted Material, as set forth at http:// nrs.harvard.edu/urn-3:HUL.InstRepos:dash.current.terms-of-use\#LAA

\section{Share Your Story}

The Harvard community has made this article openly available.

Please share how this access benefits you. Submit a story.

\section{Accessibility}




\title{
EVOLUTION OF THE PETAL AND STAMEN DEVELOPMENTAL PROGRAMS: EVIDENCE FROM COMPARATIVE STUDIES OF THE LOWER EUDICOTS AND BASAL ANGIOSPERMS
}

\author{
Elena M. Kramer ${ }^{1}$ and Vivian F. Irish \\ Department of Ecology and Evolutionary Biology, Yale University, New Haven, Connecticut 06511, U.S.A; and Department of Molecular, \\ Cellular, and Developmental Biology, Yale University, New Haven, Connecticut 06511, U.S.A.
}

\begin{abstract}
Our recently acquired understanding of the ABC program, which controls floral organ identity in model plant species such as Arabidopsis thaliana and Antirrbinum majus, has provided a new set of characters with which to evaluate floral evolution. What is still lacking, however, is a clear assessment of the actual degree of conservation of this genetic program across the angiosperms. To this end, we have begun to investigate the evolution of members of the B class gene lineages, which are known to control petal and stamen identity in the higher eudicots, and to analyze their expression patterns in selected species from the lower eudicots and basal angiosperms. The B class genes comprise the homologues of the A. thaliana genes APETALA3 (AP3) and PISTILLATA (PI), which are closely related paralogues encoding MADS box-containing DNA-binding proteins. This study has uncovered many examples of gene duplication and divergence in both the AP3 and $P I$ lineages as well as complex and variable patterns of gene expression. These findings indicate that although some aspects of the $\mathrm{ABC}$ program are conserved, others display a high degree of plasticity and may not have become fixed until later in angiosperm evolution.
\end{abstract}

Keywords: MADS box genes, AP3, PI, gene duplication, floral evolution.

\section{Introduction}

The ABC model describes how the activities of three classes of genes (termed “A," "B," and " $\mathrm{C}$ ") coordinately specify different floral organ identities (Coen et al. 1991; Meyerowitz et al. 1991). These genes function in overlapping domains such that they produce a combinatorial code that directs the developmental fate of floral organ primordia. Under this model, sepals are determined by the presence of $\mathrm{A}$ function alone, petals by $\mathrm{A}+\mathrm{B}$ function, stamens by $\mathrm{B}+\mathrm{C}$ function, and carpels by $\mathrm{C}$ function alone. Loss of any particular class of gene function results in a homeotic phenotype that affects two adjacent whorls. For example, B class mutants exhibit a transformation of petals into sepals and of stamens into carpels. The program appears to be highly conserved between the two well-studied model species Arabidopsis thaliana and Antirrhinum majus as well as among a number of other higher eudicots, such as Petunia hybrida and Nicotiana tabacum (tobacco) (reviewed by Irish and Kramer 1998). Little is known, however, about the conservation of the program outside of the higher eudicots. This is an important issue because traditionally botanists have considered the perianth (the sterile organs surrounding the stamens and carpels) to have been independently derived many times during the course of angiosperm evolution (Takhtajan 1991). One of the implications of this hypothesis is that as a result of independent derivations of petaloid organs, the establishment of petal identity in different angiosperm lineages

\footnotetext{
${ }^{1}$ Author for correspondence. Current address: Department of Organismic and Evolutionary Biology, Harvard University, Cambridge, Massachusetts 02183, U.S.A.; e-mail ekramer@oeb.harvard.edu.
}

Manuscript received February 2000; revised manuscript received May 2000. may rely on different developmental programs. In order to expand our understanding of the evolution of the ABC program-with a particular focus on the way in which petaloid organs develop-we have initiated a study of homologues of the $\mathrm{B}$ group genes in lower eudicots and basal angiosperms.

In the higher eudicots, the $B$ group genes are represented by homologues of the A. thaliana APETALA3 (AP3) and PISTILLATA (PI) genes, both of which are members of the MADS box family of DNA-binding proteins (Jack et al. 1992; Goto and Meyerowitz 1994). In the case of A. thaliana and A. majus, the gene products of the $A P 3$ and $P I$ orthologues are known to function as obligate heterodimers to promote petal and stamen identity (Schwarz-Sommer et al. 1992; Trobner et al. 1992; Jack et al. 1994). This process appears to require the expression of both genes throughout the developing petals for the duration of their development, whereas in the stamens, expression can become restricted to particular tissues as maturation proceeds (Bowman et al. 1989; Jack et al. 1992; Zachgo et al. 1995). The coexpression of the two genes is maintained by positive autoregulatory interactions such that strong continual expression of both genes appears to be dependent on the presence of a functional AP3/PI heterodimer (Schwarz-Sommer et al. 1992; Goto and Meyerowitz 1994; Jack et al. 1994).

The goal of our project is to study the evolution of the AP3 and $P I$ gene lineages in an attempt to determine whether their functions are conserved outside the higher eudicots. We have already established that the evolution of these lineages is complex, involving many gene duplication events that have often been followed by considerable sequence divergence (Kramer et al. 1998). Equally complex patterns of gene expression have been uncovered in the lower eudicots, indicating that aspects 
Table 1

All GenBank Published Representatives of the APETALA3 and PISTILLATA Gene Lineages

\begin{tabular}{|c|c|c|c|c|c|}
\hline \multirow[b]{2}{*}{ Order and family } & \multirow[b]{2}{*}{ Species } & \multicolumn{3}{|c|}{ APETALA3 lineage } & \multirow{2}{*}{$\begin{array}{l}\text { PISTILLATA } \\
\text { lineage }\end{array}$} \\
\hline & & $\mathrm{Eu} A P 3$ & TM6 & PaleoAP3 & \\
\hline \multicolumn{6}{|l|}{ Lamiales: } \\
\hline Scrophulariaceae ...... & Antirrhinum majus & $D E F$ & $\ldots$ & & GLO \\
\hline Oleaceae $\ldots \ldots \ldots \ldots \ldots$ & Syringa vulgaris & $S v A P 3$ & $\ldots$ & & $S v P I$ \\
\hline \multicolumn{6}{|l|}{ Solanales: } \\
\hline \multirow[t]{5}{*}{ Solanaceae ........... } & Petunia bybrida & PMADS1 & PbTM6 & & $\begin{array}{l}F B P 1, \\
\quad P M A D S 2\end{array}$ \\
\hline & Lycopersicon esculentum & LeAP3 & TM6 & & $\ldots$ \\
\hline & Solanum tuberosum & STDEF & PD2 & & $\ldots$ \\
\hline & Nicotiana tabacum & NTDEF & $\ldots$ & & NTGLO \\
\hline & Hydrangea macrophylla & $H m A P 3$ & НmTM6 & & $H m P I$ \\
\hline \multicolumn{6}{|l|}{ Asterales: } \\
\hline \multirow[t]{2}{*}{ Asteraceae...$\ldots \ldots \ldots$} & $\begin{array}{l}\text { Gerbera hybrida } \\
\text { var. regina compositae }\end{array}$ & GDEF2 & GDEF1 & & GGLO1 \\
\hline & $\begin{array}{l}\text { Argyroxiphium } \\
\text { sandwicense }\end{array}$ & $\cdots$ & AsAP3 & & $\cdots$ \\
\hline \multicolumn{6}{|l|}{ Brassicales: } \\
\hline Brassicaceae $\ldots \ldots \ldots$ & Arabidopsis thaliana & $A P 3$ & $\ldots$ & & $P I$ \\
\hline \multicolumn{6}{|l|}{ Myrtales: } \\
\hline Myrtaceae $\ldots . \ldots \ldots \ldots$ & Eucalyptus grandis & $\ldots$ & $\ldots$ & & EGM2 \\
\hline \multicolumn{6}{|l|}{ Fabales: } \\
\hline Fabaceae $\ldots \ldots \ldots \ldots$ & Medicago sativa & NMH7 & $\ldots$ & & $\ldots$ \\
\hline \multicolumn{6}{|l|}{ Malpighiales: } \\
\hline Salicaceae ........... & Populus tremuloides & $\ldots$ & $P T D$ & & $\ldots$ \\
\hline \multicolumn{6}{|l|}{ Caryophyllalles: } \\
\hline \multirow[t]{2}{*}{ Caryophyllaceae ...... } & Silene latifolia & SLM3 & $\ldots$ & & SLM2 \\
\hline & Dianthus caryophyllus & $\ldots$ & CMB2 & & $\ldots$ \\
\hline Polygonaceae ......... & Rumex acetosa & $R A D 1, R A D 2$ & $\ldots$ & & $\ldots$ \\
\hline \multicolumn{6}{|l|}{ Proteales: } \\
\hline Buxaceae $\ldots . . \ldots \ldots \ldots$ & Pachysandra terminalis & & & PtAP3-1 & PtAP3-2 \\
\hline \multicolumn{6}{|l|}{ Ranunculales: } \\
\hline Papaveraceae....... & Papaver nudicaule & & & PnAP3-1, PnAP3-2 & PnPI-1, PnPI-2 \\
\hline & Papaver californicus & & & PcAP3 & $\ldots$ \\
\hline & Sanguinaria canadensis & & & $S c A P 3$ & $S c P I$ \\
\hline Fumariaceae $\ldots \ldots \ldots \ldots$ & Dicentra eximia & & & DeAP3 & DePI \\
\hline Ranunculaceae ......... & Ranunculus ficaria & & & $R f A P 3-1, R f A P 3-2$ & RfPI-1, RfPI-2 \\
\hline & Ranunculus bulbosus & & & $R b A P 3-1, R b A P 3-2$ & $R b P I-1, R b P I-2$ \\
\hline & Delphinium ajacis & & & $\ldots$ & $D a P I$ \\
\hline Magnoliales: & & & & & \\
\hline Magnoliaceae ......... & Michelia figo & & & $M f A P 3$ & $M f P I$ \\
\hline & Liriodendron tulipifera & & & $L t A P 3$ & $L t P I$ \\
\hline Laurales: & & & & & \\
\hline Calycanthaceae ....... & Calycanthus floridus & & & CfAP3-1, CfAP3-2 & CfPI-1, CfPI-2 \\
\hline Piperales: & & & & & \\
\hline Aristolochiaceae ...... & Asarum europaeum & & & AeAP3-1, AeAP3-2 & $A e P I$ \\
\hline Piperaceae $\ldots . . \ldots \ldots$ & Peperomia hirta & & & PhAP3 & $P h P I$ \\
\hline & Piper magnificum & & & $\ldots$ & PmPI-1, PmPI-2 \\
\hline Chloranthales: & & & & & \\
\hline Chloranthaceae ....... & Chloranthus spicatus & & & $C s A P 3$ & $C s P I$ \\
\hline Alismatales: & & & & & \\
\hline Alismataceae ......... & Sagittaria montevidensis & & & $S m A P 3$ & $S m P I$ \\
\hline Dioscoreales: & & & & & \\
\hline Taccaceae...$\ldots \ldots \ldots$ & Tacca chantieri & & & TcAP3 & $T c P I$ \\
\hline Poales: & & & & & \\
\hline Poaceae...$\ldots \ldots \ldots$ & Oryza sativa & & & OsMADS16 & $\begin{array}{l}\text { OsMADS2, } \\
\text { OsMADS4 }\end{array}$ \\
\hline & Zea mays & & & SILKY-1 & $\ldots$ \\
\hline Coniferales: & & & & & \\
\hline Pinaceae $\ldots . . . \ldots \ldots$ & Picea abies & & & $D A L 12^{\mathrm{a}}$ & $\begin{array}{l}D A L 11^{\mathrm{a}} \\
\quad D A L 13^{\mathrm{a}}\end{array}$ \\
\hline & Pinus radiata & & & $\ldots$ & $\operatorname{PrDG} L^{\mathrm{a}}$ \\
\hline Gnetales: & & & & & \\
\hline Gnetaceae ........... & Gnetum gnemon & & & $G G M 2^{\mathrm{a}}, G G M 13^{\mathrm{a}}$ & $\ldots$ \\
\hline
\end{tabular}

Note. Genes cloned in this analysis are highlighted in bold. Species classifications are based primarily on the system proposed in APG (1998). Accession numbers are found in Kramer et al. (1998) and Kramer and Irish (1999) and in the "Material and Methods" section.

${ }^{\text {a }}$ Gymnosperm representatives are difficult to unambiguously assign to the AP3 or PI lineage and may represent an ancestral lineage predating the AP3/PI duplication. The designations in this table are based on the presence or absence of the paleoAP3 motif. 
of the genes' functions have changed over time (Kramer and Irish 1999). In this article, we will summarize these previous findings and describe the results of more recent analyses of gene sequence and expression patterns in monocot and basal angiosperm species. These results indicate that an initially plastic floral developmental program has become constrained later in the evolution of the angiosperms.

\section{Material and Methods}

\section{Cloning and Analysis}

All of the species surveyed during the course of this study are listed (along with family membership) in table 1 . Vouchers for most of the species sampled have been deposited in the Yale Herbarium. The samples of Chloranthus spicatus and Tacca chantieri were collected from specimens that are in cultivation at the New York Botanical Garden (for more detail, see Kramer 2000).

The cloning of the AP3 and PI homologues was performed in the same manner described in Kramer et al. (1998). The only exception involved the cloning of the TM6 orthologue from Petunia bybrida, PhTM6. This gene was isolated from a $\lambda$-DASH genomic library, kindly provided by Carolyn Napoli (University of Arizona). Plaques $\left(10 \times 10^{8}\right)$ were screened with a 400-bp fragment of the Lycopersicon esculentum TM6 cDNA corresponding to the $3^{\prime}$ end of the coding region. A 21$\mathrm{kb}$ clone that strongly hybridized to the TM6 probe was isolated. From this initial clone, a 4-kb HindIII fragment was found that hybridized with probes made from both the $5^{\prime}$ and $3^{\prime}$ portions of the TM6 cDNA. This 4-kb fragment was subcloned and mapped with several restriction enzymes. A 1-kb PstI/SpeI fragment that hybridized with the $3^{\prime}$ end of the TM6 cDNA was sequenced and found to contain exons with high similarity to TM6. Gene-specific primers were designed from this sequence, and the complete cDNA was amplified from a pool of first-strand cDNA made from early P. hybrida flower buds (primer sequence available upon request).

\section{Data Deposition and Phylogenetic Analysis}

The nucleotide sequences of the data corresponding to the protein sequences reported in this article have been deposited in GenBank (accession numbers AF230697-AF230713). All other sequences included in the analysis were acquired from GenBank. The majority of the accession numbers for these sequences can be found in Kramer et al. (1998) and Kramer and Irish (1999). Accession numbers for new sequences are as follows: AsAP3, AF147233; DAL11, AF158539; DAL12, AF158541; DAL13, AF158543; EGM2, AF029976; GDEF1, GHY9724; GDEF2, GHY9725; GGLO1, GHY9726; GGM2, GGN132208; GGM13, AJ132219; OsMADS16, AF077760; PrDGL, AF120097; PTD, AF057708; and SILKY-1, AF181479.

Alignments and parsimony with bootstrap analyses were performed with PAUP 4.0 (Swofford 1993), as described in Kramer et al. (1998).

\section{Northern Analysis}

For each species, the flower buds were divided into three to six stages based on their size and maturity. The perianth parts were dissected from these buds, and RNA was prepared separately from each stage. Stamen and carpel RNA was prepared from pooled organs dissected from all stages. One Nytran blot was prepared for each species (as described in Carr and Irish 1997), with $10 \mu \mathrm{g}$ of RNA per lane. Equal loading was initially assessed by ethidium bromide staining of the agarose gel. All random-primed DNA probes were made from gene-specific templates that did not include the MADS or K domains. Radionucleotide-labeled probes were cleaned on G-100 Sephadex columns, and the percent incorporation of the radionucleotide was determined. Only probes with at least $50 \%$ incorporation were used in hybridization. Hybridization was performed as described in Kramer and Irish (1999). Finally, ubiquitin control probes were hybridized to the blots after the hybridization of each of the species-specific probes had been completed.

\section{Results \\ Phylogenetic Analysis}

We have cloned representatives of the $\mathrm{B}$ class genes APETALA3 and PISTILLATA from 21 species of higher eudicots, lower eudicots, magnoliid dicots, and monocots (table 1). Phylogenetic analysis of the AP3 and PI sequences has revealed a complex pattern of gene duplication and divergence (Kramer et al. 1998; Kramer 2000). At some time before the diversification of the angiosperms, an AP3/PI ancestral gene underwent duplication and gave rise to the separate AP3 and PI lineages. In the angiosperms, the two lineages are distinguished on the basis of several characteristics. PI lineage members generally exhibit a higher degree of sequence conservation, especially in what we refer to as the PI motif at the C-terminal end of the predicted protein (fig. 1; Kramer et al. 1998). Although we have identified several duplications in this lineage, none of those uncovered to date appear to predate the diversification of any of the major angiosperm subclasses (Kramer et al. 1998; Kramer 2000).

The majority of the members of the AP3 lineage from the magnoliid dicots, monocots, and lower eudicots are characterized by the possession of a recognizable PI motif-derived region and a well-conserved paleoAP3 motif (fig. 2; Kramer et al. 1998). We refer to this lineage as the paleoAP3 lineage. An ancient duplication appears to have occurred in this lineage just prior to the diversification of the higher eudicots (fig. 3; Kramer et al. 1998; Kramer 2000). This duplication gave rise to two distinct lineages-the euAP3 and the TM6 lineages (Kramer et al. 1998). The euAP3 lineage underwent sequence diversification followed by the fixation of new characters, which include the loss of the paleoAP3 motif and its replacement with the euAP3 motif (fig. 2). Representatives of the TM6 lineage share many sequence characteristics with the ancestral paleoAP3 lineage, but these do not appear to be as highly conserved as they are in the paleoAP3 lineage proper (Kramer et al. 1998; Kramer 2000). The addition of four new TM6like genes to the data set (table 1; fig. 2) has increased the bootstrap support for the TM6 clade from 28 in the parsimony 


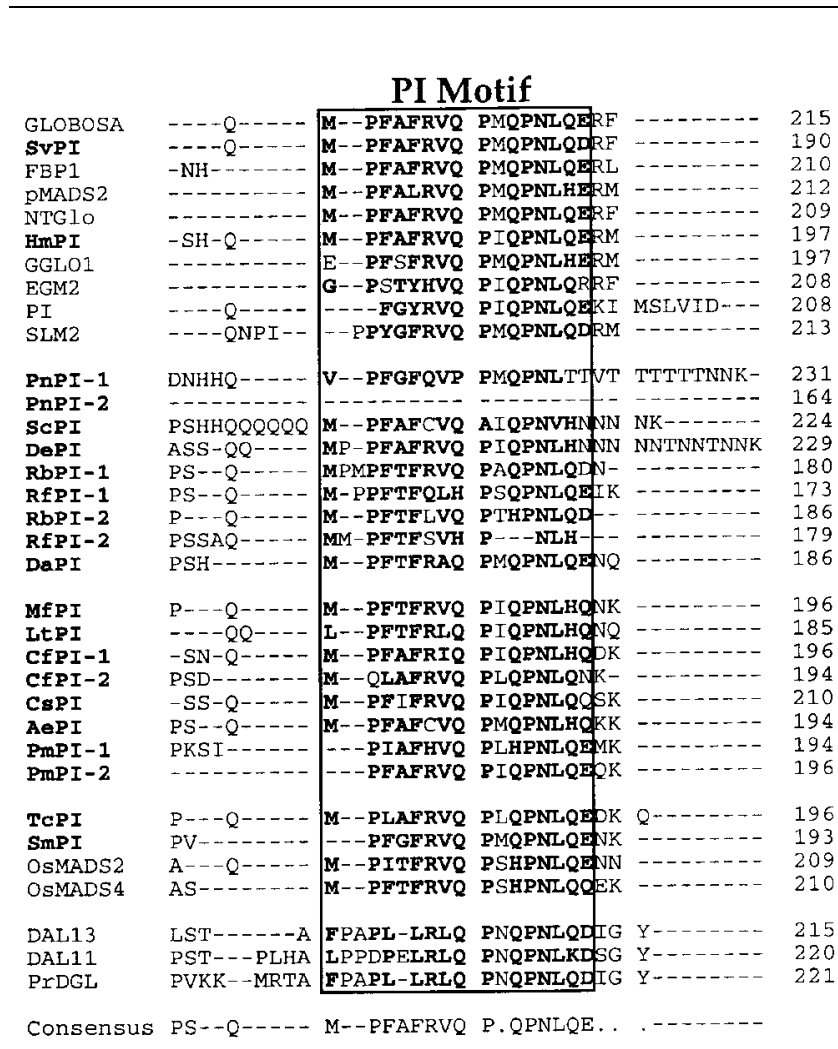

Fig. 1 Alignment of C-terminal regions of predicted PI protein sequences. The names of the genes cloned in this study are highlighted in bold. The region designated as the PI motif is boxed, and the consensus is shown below. Residues that show chemical conservation with the consensus are highlighted in bold.

analysis of Kramer et al. (1998) to 80 in our analysis (Kramer 2000). The TM6 lineage now includes unambiguous representatives from both Euasterids and Eurosids as well as what appears to be a divergent member from the Caryophyllales (table 1). In addition to the euAP3/TM6 duplication, a number of other duplication events have occurred in the paleoAP3 lineage, most of which appear to be comparatively recent (Kramer et al. 1998; Kramer and Irish 1999; Kramer 2000).

Although exact timing of the AP3/PI duplication itself is uncertain, recently identified gymnosperm $A P 3 / P I$ homologues do segregate into two classes, one with the paleo $A P 3$ motif (DAL12 and possibly GGM2 and GGM13) and one without (DAL11, DAL13, and PrDGL) (figs. 1, 2; Mouradov et al. 1999; Sundstrom et al. 1999; Winter et al. 1999). Both classes possess recognizable PI motifs. The existence of the two classes indicates that the AP3/PI duplication may have predated the separation of gymnosperms and angiosperms (fig. 3; Hasebe 1999) and was followed by a loss of the paleoAP3 motif in the $P I$ lineage (or, alternatively, the acquisition of the paleoAP3 motif in the AP3 lineage). However, phylogenetic analyses are currently inconclusive with regard to the exact position of the gymnosperm genes relative to the angiosperm AP3 and PI lineages (Sundstrom et al. 1999; Kramer 2000). We hope that additional sequence data from the gymnosperms and lower land plants will clarify the question of when the AP3/PI duplication occurred.
The multiple duplication and divergence events that have occurred in both of the AP3 and PI lineages complicate the phylogenetic analysis and make the discussion of gene orthology difficult. There are recognizable trends of sequence conservation in the different lineages, however, which may reflect changing functional repertoires. Retention of duplicate gene copies, like that observed with AP3 and PI representatives in many species, is often stabilized by the acquisition of novel functions (Fryxell 1996; Cooke et al. 1997). The duplicate genes may diverge in such a way that one acquires totally unique functions while the other maintains the ancestral function (Ohno 1970). Alternatively, the ancestral functions may become partitioned between the two paralogues, resulting in a state of functional complementation that serves to maintain the duplicate copies (Force et al. 1999). Examples of these phenomena (and of others) are common in the literature (Fryxell 1996; Force et al. 1999; Ganfornina and Sanchez 1999), but it can be difficult to determine exactly how any particular pair of paralogues may be diverging in function.

\section{Expression Analysis}

In order to begin to address the question of divergence of gene function, we examined the expression patterns of paleoAP3 and PI representatives in 10 different species using Northern blot analysis, in situ hybridization, and antibody staining. The expression patterns observed are quite variable in several aspects (summarized in table 2) and, in general, are not consistent with what is known about the way that euAP3 and $P I$ gene products function to establish higher eudicot petal identity. In two of the species studied, representatives of both the paleoAP3 and PI lineages were expressed at moderate to high levels in the developing sepals (table 2; Sanguinaria canadensis and Sagittaria montevidensis). This is a surprising finding because in the higher eudicots that have been examined, first whorl expression of euAP3 and PI orthologues is sufficient to transform sepals into petals (Halfter et al. 1994; Davies et al. 1996; Krizek and Meyerowitz 1996).

Expression of paleo $A P 3$ and $P I$ lineage members was generally present in all of the petaloid organs we examined, regardless of whether they were found in a bipartite perianth (one having both sepals and petals) or in a unipartite perianth (one having only one type of organ, in this case, petaloid organs called tepals). However, the details of the expression patterns in these petaloid organs varied considerably. Although many species exhibited moderate to strong expression at early stages of development, the petaloid organs of Calycanthus floridus and Liriodendron tulipifera did not. We observed spatial restriction of expression within the petals of several species from the ranunculids (Kramer and Irish 1999; Kramer 2000) but also in the tepals of the magnoliid Michelia figo and the monocot S. montevidensis (Kramer 2000). This spatial restriction took many forms. In some cases, expression appeared to be localized to the tip or base of the developing organ, whereas in other cases, the transcript was restricted to one side of the organ (i.e., the adaxial half) or even to one cell layer (i.e., the adaxial epidermis) (Kramer and Irish 1999; Kramer 2000). In addition, we found that in many species, the genes exhibited dynamic changes in the level of expression over the course 


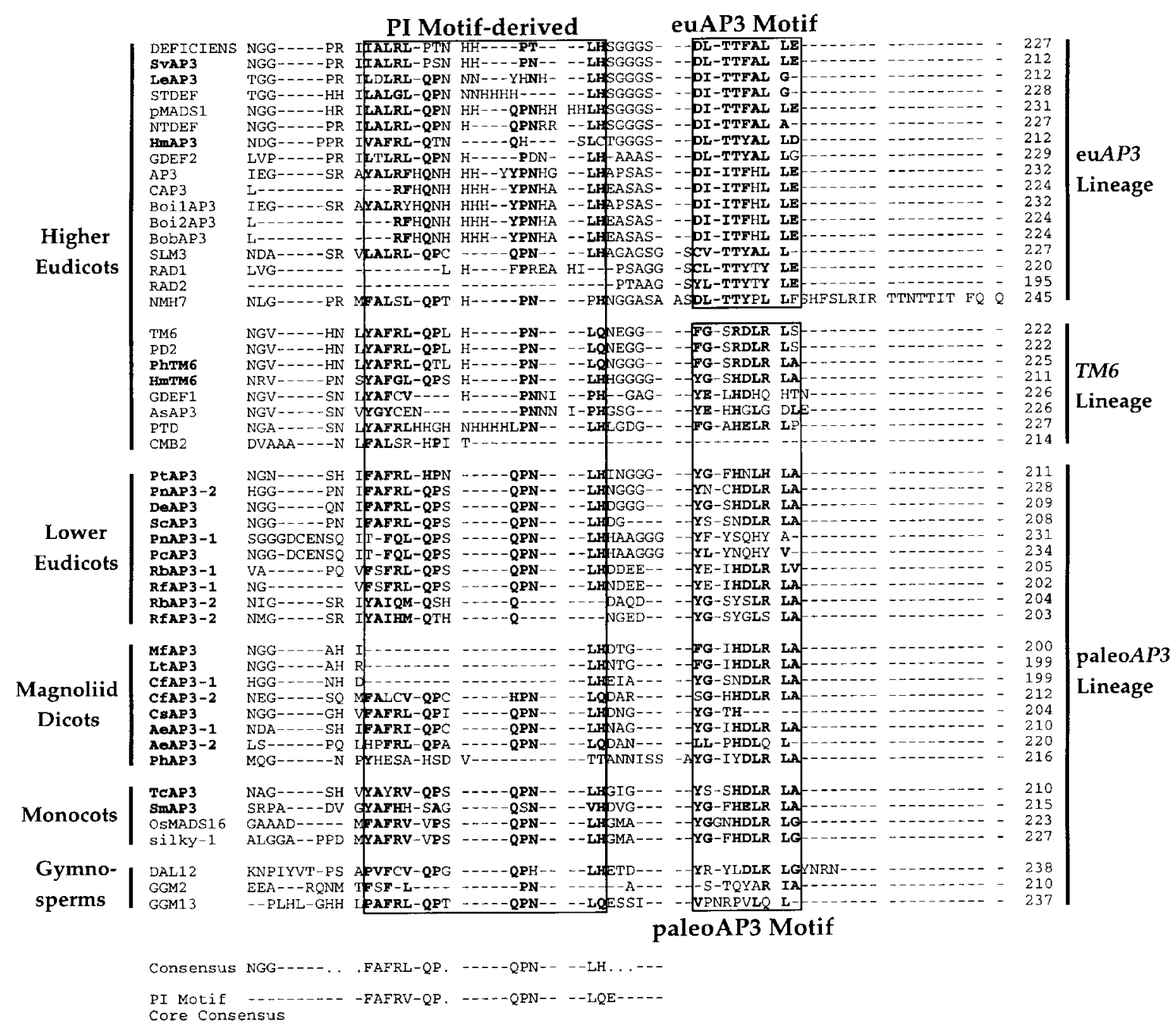

Fig. 2 Alignment of C-terminal regions of the predicted AP3 homologue proteins. The names of genes cloned in this study are highlighted in bold. Genes are grouped according to lineage as indicated by the presence of certain synapomorphies and as determined by phylogenetic analysis. The region that bears similarity to the PI motif is boxed and defined as PI motif-derived. Residues that show chemical conservation with the PI motif core consensus are highlighted in bold. The C-terminal euAP3 and paleoAP3 motifs are also indicated with boxes. Residues in each region that show chemical conservation with the euAP3 motif consensus (DLTTFALLE) or the paleoAP3 consensus (YGxHDLRLA) are highlighted in bold. It should be noted that the designations of these motifs, particularly the paleoAP 3 motif, in the gymnosperm representatives GGM2 and GGM13 are somewhat unclear.

of organ development (table 2; Kramer and Irish 1999). Another notable finding was that in more basal species, such as C. floridus and Asarum europaeum, the PI representatives were expressed alone or at much higher levels than were the paleo $A P 3$ representatives (fig. $4 A, 4 B$ ). These results are significant since they contrast sharply with the expression patterns of euAP3 and PI orthologues observed in the higher eudicots and because they indicate that the paleoAP3 and PI gene products may be able to function as homodimers or may be able to heterodimerize with as-yetunidentified partners.

Unlike what we observed in the petaloid organs, the basic pattern of gene expression in the developing stamens of the species we examined was very similar to what has been observed in the higher eudicots. In most species, paleoAP3 and $P I$ representatives are expressed in the stamen primordia from the earliest stages but become restricted to specific tissue types (usually the sporangial tissue) later in development. Expression is lost as the stamens approach maturity and as the pollen begins to mature (Kramer and Irish 1999; Kramer 2000). This conserved pattern of expression indicates that once stamen identity has been established, multiple genetic programs, some involving AP3 and PI lineage members, promote the development of different parts of the organ. In C. floridus and A. europaeum, the $P I$ representatives were strongly expressed in the stamens without the paleo $A P 3$ orthologues (fig. 4), indi- 


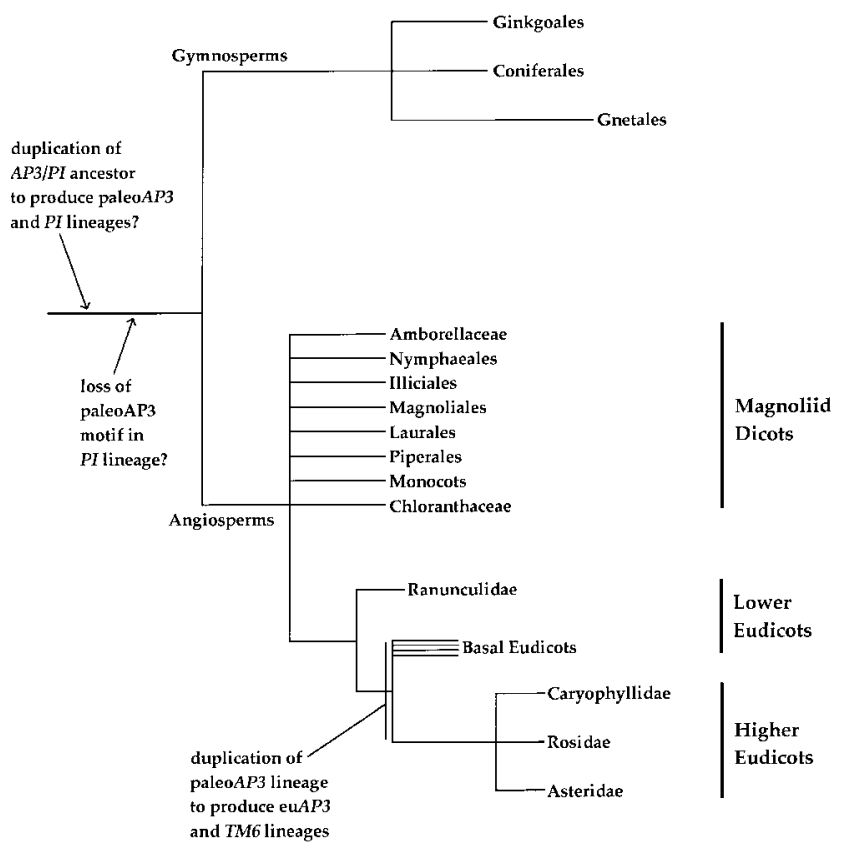

Fig. 3 Simplified phylogeny of seed plants (based on Qiu et al. 1999 and Soltis et al. 1999). The major events in the evolution of the AP3/PI gene lineages are mapped onto the phylogeny.

cating that these $P I$ gene products may be determining stamen identity on their own or with a partner other than the paleo $A P 3$ gene product.

PaleoAP3 and PI representatives may also play a role in carpel development, particularly ovule development. In situ and antibody analyses have repeatedly revealed strong expression of paleoAP3 and PI lineage members in the placenta and the developing ovule (Kramer and Irish 1999; Kramer 2000). Interestingly, euAP3 and PI representatives have been found to display similar expression patterns in several higher eudicot species, although the expression is always limited to either euAP3 or PI (Irish and Kramer 1998). Mutations of these genes in higher eudicots do not disrupt ovule development, leading to the assumption that their expression in the ovules is not required for normal ovule development (Sommer et al. 1991; Jack et al. 1992). It now appears that the higher eudicot ovule expression of either euAP3 or PI may have been inherited from the paleo $A P 3$ and $P I$ ancestors. To date, the function of paleoAP3 and PI representatives in ovule development is unknown.

\section{Discussion}

\section{A Historical Perspective}

The classical view of floral evolution is that while stamens and carpels evolved only once, petaloid perianth organs have evolved multiple times, in some cases being derived from bracts and in others from stamens (Eames 1961; Bierhorst 1971; Takhtajan 1991). This idea is based in part on paleontological evidence that indicates that early angiosperms did not possess a well-developed perianth (Stewart and Rothwell 1993; Sun et al. 1998), and therefore, this idea assumes that the common ancestor of the angiosperms was apetalous (Endress 1994a). The main support for the hypothesis of independent petaloid organ derivations comes from morphological studies that indicate that the petaloid perianth organs of various angiosperm lineages exhibit many fundamental differences. Based on these differences, petaloid organs can be grouped into two classes. Petals, which by definition are members of a bipartite perianth (Heywood 1993), exhibit a suite of characteristics that are thought to affiliate them with stamens. These characters include the following: petals are developmentally delayed relative to the stamens; petals are arranged on the same parastichies as the stamens (if they are spirally arranged, they are more commonly arranged in whorls in positions alternate to the stamens); petals are similar in appearance to stamen primordia at inception; petals are supplied by a single vascular trace; and, in some cases, petals possess nectaries (Takhtajan 1991; Endress 1994a). This group of characters is thought to reflect the fact that petals were derived from stamens by means of a gradual process of sterilization and elaboration (Eames 1961), and for this reason, these types of petaloid organs are sometimes referred to as andropetals (Takhtajan 1991). The second type of petaloid organ, known as the tepal, is found in unipartite perianths and is generally more leaflike in its characteristics. Typically tepals are initiated and mature much earlier than the do the stamens; they are often spirally arranged on the same parastichies as the subtending bracts; their primordia are distinctly crescent shaped; they are supplied by three vascular traces; and they are generally more leaflike in their appearance than are petals (Smith 1926, 1928; Tucker 1960; Takhtajan 1991). Tepals are therefore generally thought to be derived from the bracts that surround the flower (Eames 1961) and are termed "bracteopetals" (Takhtajan 1991).

There are, of course, exceptions to these generalizations, the petaloid perianth organs of the monocots being a good example. The monocot perianth is typically unipartite and is made up of petaloid organs only; these organs are referred to as tepals. Like other tepals, monocot tepals generally do not display developmental retardation relative to the stamens, but they do possess many other characteristics that are usually associated with andropetals. This fact has led to disagreement over whether the monocot perianth is bracteally or staminally derived (Bierhorst 1971; Takhtajan 1991). Regardless of which theory on monocot tepal derivation one proposes, however, the distribution across the angiosperms of andropetals and bracteopetals seems to indicate that there are multiple origins of each type (Eames 1961; Takhtajan 1991).

\section{Recent Advances in Molecular Genetics Provide New Viewpoints}

Since the discovery that very similar genetic programs function to establish floral organ identity in both Arabidopsis thaliana and Antirrhinum majus (Coen and Meyerowitz 1991), two species with considerably different floral morphologies, it has been suggested that many aspects of the variation in angiosperm floral morphology could be explained by modifica- 
Table 2

Summary of Expression Patterns

\begin{tabular}{|c|c|c|c|c|c|c|c|}
\hline Family/species/genes & Sepals & $\begin{array}{c}\text { Early-stage } \\
\text { petaloid } \\
\text { organ }\end{array}$ & $\begin{array}{c}\text { Midstage } \\
\text { petaloid } \\
\text { organs }\end{array}$ & $\begin{array}{c}\text { Late-stage } \\
\text { petaloid } \\
\text { organs }\end{array}$ & $\begin{array}{l}\text { Spatial } \\
\text { restriction }\end{array}$ & Stamens & Carpels \\
\hline \multicolumn{8}{|l|}{ Papaveraceae: } \\
\hline \multicolumn{8}{|l|}{ Papaver nudicaule: } \\
\hline PnAP3-1 .............. & - & + & ++ & +++ & $\mathrm{Y}$ & ++ & + \\
\hline PnAP3-2 ............ & - & - & + & ++ & $\mathrm{Y}$ & +++ & + \\
\hline PnPI-1 ............... & - & + & + & ++ & $\mathrm{Y}$ & + & + \\
\hline PnPI-2 ............... & - & + & - & - & nd & - & - \\
\hline \multicolumn{8}{|l|}{ Sanguinaria canadensis: } \\
\hline ScAP3 $\ldots \ldots \ldots \ldots \ldots$ & ++ & nd & ++ & +++ & nd & +++ & ++ \\
\hline$S_{c P I} \ldots \ldots \ldots \ldots \ldots \ldots$ & ++ & nd & ++ & +++ & nd & +++ & - \\
\hline \multicolumn{8}{|l|}{ Fumariaceae: } \\
\hline \multicolumn{8}{|l|}{ Dicentra eximia: } \\
\hline DeAP3 $\ldots \ldots \ldots \ldots \ldots$ & - & + & + & ++ & $\mathrm{Y}$ & ++ & ++ \\
\hline DEPI $\ldots \ldots \ldots \ldots \ldots \ldots$ & - & ++ & ++ & ++ & $\mathrm{Y}$ & ++ & + \\
\hline \multicolumn{8}{|l|}{ Ranunculaceae: } \\
\hline \multicolumn{8}{|l|}{ Ranunculus ficaria: } \\
\hline RfAP3-1 $\ldots \ldots \ldots \ldots$ & - & - & - & ++ & Y & ++ & - \\
\hline RfAP3-2 .............. & - & + & + & - & $\mathrm{Y}$ & +++ & + \\
\hline$R f P I-1 \quad \ldots \ldots \ldots \ldots \ldots$ & - & + & + & + & $\mathrm{N}$ & + & - \\
\hline$R f P I-2 \ldots \ldots \ldots \ldots \ldots$ & - & + & ++ & + & $\mathrm{N}$ & + & - \\
\hline \multicolumn{8}{|l|}{ Ranunculus bulbosus: } \\
\hline RbAP3-1 .............. & + & + & +++ & ++ & nd & +++ & - \\
\hline RbAP3-2 ................ & - & + & +++ & ++ & nd & + & - \\
\hline RbPI-1 $\ldots \ldots \ldots \ldots \ldots$ & - & + & +++ & ++ & nd & ++ & - \\
\hline RbPI-2 $\ldots \ldots \ldots \ldots \ldots$ & - & + & +++ & ++ & nd & + & - \\
\hline \multicolumn{8}{|l|}{ Magnoliaceae: } \\
\hline \multicolumn{8}{|l|}{ Michelia figo: } \\
\hline$M f A P 3 \quad \ldots \ldots \ldots \ldots \ldots$ & NA & ++ & ++ & ++ & $\mathrm{Y}$ & ++ & ++ \\
\hline MfPI ................ & NA & + & + & ++ & $\mathrm{N}$ & +++ & ++ \\
\hline \multicolumn{8}{|l|}{ Liriodendron tulipifera: } \\
\hline$L t A P 3 \quad \ldots \ldots \ldots \ldots \ldots$ & nd & - & ++ & - & $\mathrm{N}$ & +++ & + \\
\hline$L t P I \ldots \ldots \ldots \ldots \ldots \ldots$ & nd & - & ++ & +++ & $\mathrm{N}$ & +++ & + \\
\hline \multicolumn{8}{|l|}{ Calycanthaceae: } \\
\hline \multicolumn{8}{|l|}{ Calycanthus floridus: } \\
\hline 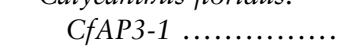 & NA & $+1-{ }^{b}$ & $+/+$ & $+/+$ & nd & - & - \\
\hline CfAP3-2 ............. & NA & $-1-$ & $+1-$ & $+1-$ & nd & - & - \\
\hline CPPI-1 ................ & NA & $-1+$ & $+/++$ & $+/+++$ & nd & ++ & ++ \\
\hline CfPI $-2 \ldots \ldots \ldots \ldots \ldots$ & NA & $+/+$ & $+/+$ & $+/++$ & nd & - & + \\
\hline \multicolumn{8}{|l|}{ Aristolochiaceae: } \\
\hline \multicolumn{8}{|l|}{ Asarum europaeum: } \\
\hline AeAP3-1 ............ & + & NA & NA & NA & nd & - & - \\
\hline AeAP3-2 $\ldots \ldots \ldots \ldots . .$. & - & NA & NA & NA & nd & - & + \\
\hline AePI $\ldots \ldots \ldots \ldots \ldots \ldots$ & - & NA & NA & NA & nd & ++ & - \\
\hline \multicolumn{8}{|l|}{ Alismataceae: } \\
\hline \multicolumn{8}{|l|}{ Sagittaria montevidensis: } \\
\hline SmAP3 & ++ & +++ & +++ & +++ & Y & ++ & + \\
\hline $\operatorname{SmPI} \ldots \ldots \ldots \ldots \ldots \ldots$ & ++ & +++ & +++ & +++ & $\mathrm{Y}$ & ++ & ++ \\
\hline
\end{tabular}

Note. Expression patterns were assessed using Northern blot, in situ hybridization, and immunolocalization (Kramer and Irish 1999; Kramer 2000). Expression levels are indicated as follows: $-=$ undetectable; $+=$ barely detectable; $++=$ intermediate in terms of detection; $+++=$ strongly expressed, similar to ubiquitin expression; and NA $=$ not applicable.

${ }^{a}$ Whether spatial restriction of expression was observed using in situ hybridization or antibody localization $(\mathrm{Y}=\mathrm{Yes}, \mathrm{N}=\mathrm{No}$, nd $=$ not done).

b The innermost tepals of Calycanthus, which bear food bodies and have staminal characteristics, were separated from the outer tepals. The expression patterns observed for the outer tepals are shown before the hash mark; the second value indicates the expression observed in the staminoid inner tepals (see fig. $4 A$ ). 
tions in a commonly inherited ABC program (Meyerowitz et al. 1991; Bowman 1997; Albert et al. 1998). For example, transitions between unipartite and bipartite perianths could simply result from changes in the expression domain of the $\mathrm{B}$ group genes (Bowman 1997; Albert et al. 1998). This hypothesis proposes that orthologues of the A, B, and C class genes are functioning in a conserved manner to establish floral organ identities throughout the angiosperms (Bowman 1997; Albert et al. 1998). One implication of this idea is that all extant angiosperms are descended from a common ancestor that possessed petaloid organs and that these organs were determined by the $\mathrm{A}+\mathrm{B}$ code in a manner similar to what we observe in the higher eudicots (Baum 1998).

Alternatively, we could hypothesize that the conservation of the combinatorial role of A and B group gene orthologues in establishing perianth organ identity may be restricted to the higher eudicots. In this case, stamen and carpel identity programs would still be expected to be conserved across the angiosperms, but in the lower eudicots, magnoliids, and monocots, independent derivations of petaloid organs may be correlated with differences in the programs that establish petaloid identity. A or B group gene homologues could still be involved in the development of petaloid organs, but this involvement would reflect their independent recruitment to such a role (Theissen et al. 2000). This model is more consistent with the idea that the last common ancestor of extant angiosperms did not possess petaloid organs.

\section{Our Survey of the B Class Genes Outside the Higher Eudicots and Its Implications}

Our data do not seem to support the hypothesis that the $\mathrm{ABC}$ program is strictly conserved throughout the angiosperms. In the higher eudicots examined to date, the ability of euAP3 and PI lineage members to establish petal identity is dependent on their mutual, constant, and ubiquitous expression in the developing petal (Bowman et al. 1989; Carpenter and Coen 1990; Zachgo et al. 1995; P. Jenik and V. F. Irish, unpublished manuscript). In order to maintain petal identity, it appears that the presence of the euAP3/PI heterodimer is necessary in every cell of the petal until quite late in development, perhaps up to the last cell division. However, the pattern of paleoAP3 and PI orthologue expression and protein localization observed in the lower eudicots, magnoliid dicots, or monocot species examined does not fit this model. Instead, the spatially restricted and temporally dynamic paleo $A P 3$ and $P I$ expression patterns in these species indicate that the genes are not establishing petal identity in the same way as are the euAP3 and PI representatives in the higher eudicots. Another complication revealed by the expression data is the possibility that the gene products of some magnoliid dicot PI lineage representatives, and possibly those of the paleo $A P 3$ lineage as well, do not function as obligate heterodimers but rather may have the capability of functioning as homodimers. These results indicate that the biochemical and developmental functions of $A P 3$ and PI lineage members may have undergone considerable change over the course of angiosperm evolution.

There are two currently indistinguishable models that could explain our data. The first model holds that the variable ex- pression of AP3 and PI homologues in petaloid organs reflects truly independent derivation events from stamens or bracts. The shared expression of AP3 and PI lineage members in many petaloid organs could be a result of the repeated recruitment of these genes to function in the development of petaloid organs. The derivation of such organs from stamens, which already express $A P 3$ and $P I$ homologues, makes it likely that andropetals would also utilize these genes in their development. The diverse expression patterns we have observed may reflect the different ways that the preexisting AP3 and PI gene products were integrated into a petal development program. By the same token, some bracteally derived petaloid organs might also express AP3 and PI homologues. As several authors have noted, the derivation of petaloid organs from bracts could have involved the expansion of AP3/PI expression from the stamens into preexisting sterile organs (Bowman 1997; Baum 1998).

This type of co-option is a commonly observed phenomenon in comparative studies of animal development, in which it has repeatedly been shown that the expression of homologous genes is not always a reliable indicator of organ homology (Dickinson 1995; Bolker and Raff 1996; Muller and Wagner 1996; Abouheif et al. 1997; Wray and Abouheif 1998). These cases reflect the co-option of gene products or whole pathways to function in novel structures (Davidson and Ruvkin 1999). The repeated independent recruitment of the same genetic pathways for similar functions is especially relevant to plant evolution, in which structures appear to have been independently derived many times from the same precursor. These structures may express very similar developmental programs in spite the fact that they are not actually homologous.

The second hypothesis consistent with our results is that we are seeing the effects of a commonly inherited but variable developmental program. Under this interpretation, the repeatedly observed presence of $A P 3$ and $P I$ transcripts in petaloid organs reflects the inheritance of a petal identity program from a common ancestor. This idea is a variation on the proposal that the $\mathrm{ABC}$ program is universally conserved. Our results do not support strict conservation, however. Under this model, our data would indicate that while the stamen identity program was established before the radiation of the angiosperms, the petal identity program must have remained plastic until later in angiosperm evolution, becoming fixed somewhere along the lineage leading to the higher eudicots.

In support of this hypothesis, it is interesting to note that careful developmental analyses of Arabidopsis floral homeotic mutants indicate that, particularly in the first and second whorls, characters such as organ phyllotaxy and early primordium growth are genetically dissociable from organ identity (Bowman et al. 1989; Hill and Lord 1989; Crone and Lord 1994; Jenik and Irish 2000). This observation may cast doubt on the reliability of such characters as indicators of independent petal derivation events. In addition, it has been noted by several authors that the distinctions that classical botanists have made between tepals and petals tend to confuse the separate characters of perianth organ appearance (petaloid vs. sepaloid) and perianth structure (unipartite vs. bipartite) (Albert et al. 1998; Baum and Whitlock 1999). Consideration of these factors increases the plausibility of a single evolution 


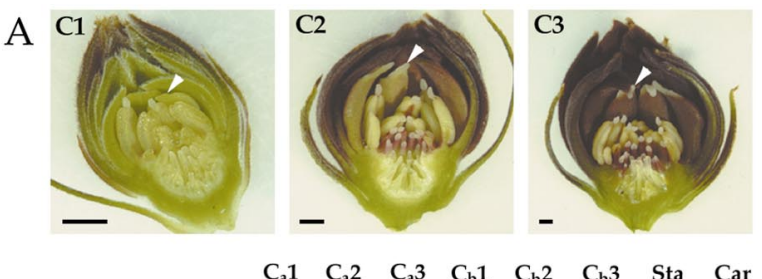

CfAP3-1

CfAP3-2

CfPI-1

CfPI-2
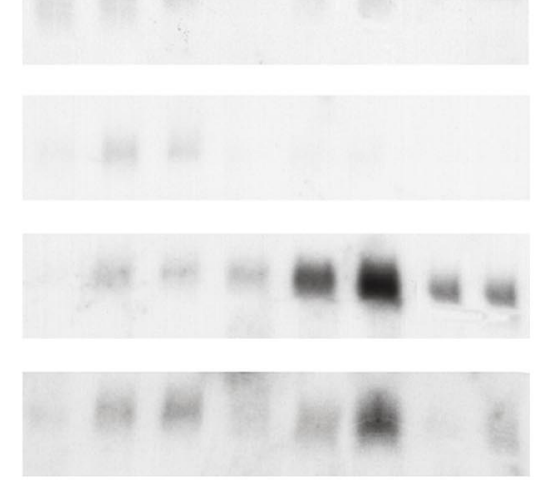

Ubiq.
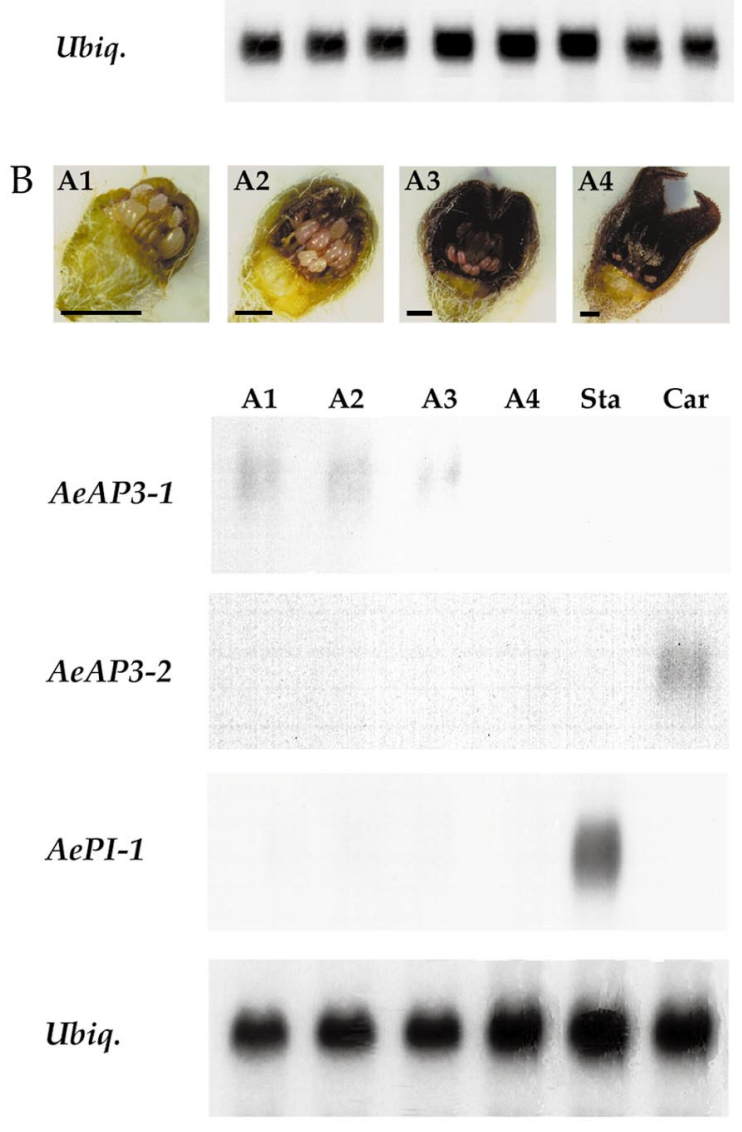

Fig. 4 Northern blot analysis of Calycanthus floridus and Asarum europaeum. A, Northern blot analysis of CfAP3-1, CfAP3-2, CfPI-1, and $C f P I-2$ in C. floridus. Three stages of floral development were examined: $C 1$, buds $0.25-0.5 \mathrm{~cm}$ in size; $C 2$, buds $0.5-1.0 \mathrm{~cm}$; and $C 3$, buds $1.0-1.5 \mathrm{~cm}$. The innermost tepals bearing food bodies and of petaloidy followed by many derivations of bipartite perianths.

The truth most likely lies in a combination of these two models: some lineages may possess petaloid organs that are genuinely independently derived, whereas the majority of the angiosperms may express a commonly inherited but often variable petal identity program. The high degree of variation in floral morphology that is found in the lineages of the magnoliid grade correlates well with the hypothesis that the ABC program was not rigidly fixed during the earliest stages of angiosperm evolution. The morphology of flowers in these families is highly labile with regard to phyllotaxis, organ number, and differentiation of the perianth, among other characteristics. It has been assumed that this morphological plasticity reflects a low level of integration of the perianth parts into the overall floral structure and allows for the frequent reduction and loss of perianth parts (Endress 1986b, 1994b). This would seem to indicate that many aspects of the floral developmental program were unconstrained in the earliest angiosperms; including, the pathways controlling everything from floral organ identity to organ phyllotaxy to developmental kinetics. It is currently impossible to tell whether some degree of this flexibility reflects many independent petal derivation events or merely a commonly inherited program that remained labile.

By contrast, the floral morphology of the monocots is much more constrained than that of their magnoliid ancestors: phyllotaxy is distinctly whorled, organ number per whorl is fixed at three, and there is a strong tendency toward a unipartite perianth (Dahlgren et al. 1984; Endress 1987). The theory that some aspects of the B class genes' petal identity function evolved before the last common ancestor of eudicots and monocots would seem to be supported by the B-type homeotic phenotypes observed in monocots, such as the viridaflora cultivar of Tulipa (van Tunen et al. 1993). We must keep in mind, however, that although these mutants clearly reflect an association between petal and stamen identity, we cannot rule out an independent derivation of petals from stamens in these lineages. Along the same lines, it has been found that the loss of paleoAP3 or PI representative function in derived monocots such as Zea mays and Oryza sativa results in a transformation of lodicules into palea/lemma-like organs and of stamens into carpeloid organs (Kang et al. 1998; Ambrose et al. 2000). These results do not, however, necessarily imply that the lodicule is historically homologous to the higher eudicot petal (Ambrose et al. 2000; Ma 2000) or even to the petals of more primitive monocots. The data currently on hand could also be consistent with the theory that lodicules represent sterilized stamens (Clifford 1987; Cocucci and Anton 1988), which could conceivably express B group genes, reflecting their staminal derivation, but not $\mathrm{C}$ group genes (as a result of their

possessing staminal characteristics (designated $C_{b}$ ) were separated from the outer tepals (designated $C_{a}$ ). Sta $=$ stamens; $C a r=$ carpels. Arrows indicate inner tepals with partial staminal characteristics (whorl b). Scale bar $=5 \mathrm{~mm}$. B, Northern blot analysis of AeAP3-1, AeAP3-2, and AePI-1 in A. europaeum. Total RNA was prepared from four stages of spring buds: $A 1,2.5 \mathrm{~mm} ; A 2,5 \mathrm{~mm}$; A3, $7.5 \mathrm{~mm}$; and A4, $1.0-1.5 \mathrm{~cm}$. Sta $=$ stamens; Car $=$ carpels. Scale bar $=1 \mathrm{~mm}$. 
sterilization). We must also consider the inherent danger of comparing highly divergent model species in the absence of substantial data from intervening taxa (Bolker 1995; Bang et al. 2000)

The ranunculids, which represent the basalmost eudicots, would seem to have relatively stable floral morphology compared with the magnoliids. They often display whorled bipartite perianths, particularly in the Papaverales and Ranunculaceae (Magallon et al. 1999). At the same time, there are ranunculid families with comparatively unstable floral morphologies, and interestingly, Euptelea, the genus recently identified as sister to the Ranuculales (Magallon et al. 1999), has small apetalous flowers with a variable number of stamens and carpels (Endress 1986a). This could indicate that the stability of floral structure within the Papaverales and the Ranunculaceae represents independent canalizations of floral development. Consistent with this idea, the Ranunculaceae are the best-studied and most commonly cited example of independent derivations of andropetals (Kosuge 1994; Albert et al. 1998). The rest of the basal eudicots, which are positioned intermediately between the ranunculids and the higher eudicots, display even greater morphological variation, ranging from the large multiparted flowers of Nelumbo (lotus) to the small reduced flowers of Platanus (sycamore). Overall, these observations would seem to indicate that the floral developmental program was still relatively plastic in the basal eudicots, a conclusion that is supported by the variation in expression patterns of paleoAP3 and PI lineage members that we have observed across several ranunculid species (Kramer and Irish 1999).

Another major canalization of floral development appears to have occurred just prior to the diversification of the higher eudicots. In this monophyletic group, whorled phyllotaxy is predominant; organ number per whorl, although not absolutely fixed, tends to number four or five; and a bipartite perianth is common (Magallon et al. 1999). This "synorganization of parts," as Endress calls it (Endress 1987), has allowed for flexibility at other levels of floral organization, favoring elaborations such as syncarpy and sympetaly (Endress 1987, 1994a). It is notable that this canalization coincides with the euAP3/TM6 duplication and the apparent fixation of euAP3/ $P I$ petal expression patterns. The loss of ancestral paleoAP3 characters, including the paleoAP3 motif, and the fixation of new characters (i.e., the euAP3 motif) may be correlated with a broader process of floral evolution, a process that was under way in the higher eudicot ancestor. However, the refinement of floral morphology that predates the diversification of the higher eudicots obviously involved many aspects of the floral developmental program in addition to organ identity. It has been observed that the lineages of the higher eudicots underwent very rapid radiations involving high speciation rates, which gave rise to $75 \%$ of all angiosperm species (Magallon et al. 1999). It is intriguing to consider that the canalization of floral development that occurred along the lineage leading to the higher eudicot clade, in part reflecting the fixation of the $\mathrm{ABC}$ program, may have been an important factor underlying this extraordinary diversification.

\section{Future Prospects}

When we initiated this study of the AP3 and PI gene lineages, relatively little was known about the evolution of these genes within the angiosperms or about their expression patterns outside the higher eudicots. The complex patterns of gene duplication and the variability in expression patterns that we have uncovered still leave many questions unanswered; in addition, these factors raise new questions. First of all, we need to achieve a more complete understanding of the evolution of these gene lineages. When did the major duplications, particularly the euAP3/TM6 duplication, occur? How have differing rates of sequence divergence shaped the members of these lineages? The second group of questions that this analysis has raised relates to the evolution of the biochemical function of the AP3 and PI lineage members. We currently have no information regarding the functional role of the three highly conserved motifs: the PI motif, the paleoAP3 motif, and the euAP3 motif. In particular, it is important to understand the functional role of the paleoAP3 motif versus the euAP3 motif and what these roles may reflect concerning the evolution of petal identity function in the higher eudicots. We must also consider the issue of dimerization specificity and how it may have changed over the course of angiosperm evolution.

Now that it has been established that the expression patterns of AP3 and PI lineage members do, in fact, vary across the angiosperms, we need to establish exactly how variable this character is in order to determine its usefulness. This investigation must include a more careful study of euAP3 orthologue expression patterns in the higher eudicots so that we can make accurate comparisons and determine when the characteristic higher eudicot expression pattern became fixed (if it actually is as fixed as it appears to be). Furthermore, the expression of TM6 lineage members in the higher eudicots is virtually unknown, presenting an obvious target for study. Overall, however, the critical information will come from the direct functional analysis of these gene products, an analysis that will require the development of transgenic and genetic techniques in nontraditional model species. Finally, the synthesis and interpretation of all of this data will require a robust phylogeny of the angiosperm lineages.

Realistically, it may be very difficult to discretely distinguish between a commonly inherited yet variable developmental program and multiple independently derived programs that utilize homologous genes as a result of recruitment. Nonetheless, more detailed analyses of the expression patterns and functions of the floral homeotic genes across the angiosperms may, in the end, allow us to determine how these developmental programs evolved and how such changes have produced the morphological diversity observed in angiosperm flowers.

\section{Acknowledgments}

We thank Leo Hickey, Gunter Wagner, Amy Litt, Iain Dawson, Pablo Jenik, Rebecca Lamb, Michael Purugganan, and an anonymous reviewer for helpful discussions and comments on this manuscript. This work was supported by National Science Foundation grant IBN-9808118 to V. F. Irish. 


\section{Literature Cited}

Abouheif E, M Akam, WJ Dickinson, PWH Holland, A Meyer, NH Patel, RA Raff, VL Roth, GA Wray 1997 Homology and developmental genes. Trends Genet 13:432-433.

Albert VA, MHG Gustafsson, L Di Laurenzio 1998 Ontogenetic systematics, molecular developmental genetics, and the angiosperm petal. Pages 349-374 in D Soltis, P Soltis, JJ Doyle, eds. Molecular systematics of plants. Vol 2. Chapman \& Hall, New York.

Ambrose BA, DR Lerner, P Ciceri, CM Padilla, MF Yanofsky, RJ Schmidt 2000 Molecular and genetic analyses of the silky1 gene reveal conservation in floral organ specification between endicots and monocots. Mol Cell 5:569-579.

APG 1998 An ordinal classification for the families of the flowering plants. Ann Mo Bot Gard 85:531-553.

Bang R, R DeSalle, W Wheeler 2000 Transformationalism, taxism and developmental biology in systematics. Syst Biol 49:19-27.

Baum DA 1998 The evolution of plant development. Curr Trends Plant Sci 1:79-86.

Baum DA, BA Whitlock 1999 Genetic clues to petal evolution. Curr Biol 9:525-527.

Bierhorst DW 1971 Morphology of vascular plants. Macmillan, New York.

Bolker JA 1995 Model systems in developmental biology. Bioessays 17:451-455.

Bolker JA, RA Raff 1996 Developmental genetics and traditional homology. Bioessays 18:489-494.

Bowman

JL 1997

Evolutionary conservation of angiosperm flower development at the molecular and genetic levels. J Biosci 22:515-527.

Bowman JL, DR Smyth, EM Meyerowitz 1989 Genes directing flower development in Arabidopsis. Plant Cell 1:37-52.

Carpenter R, ES Coen 1990 Floral homeotic mutations produced by transposon-mutagenesis in Antirrhinum majus. Genes Dev 4: 1483-1493.

Carr S, VF Irish 1997 Floral homeotic gene expression defines developmental arrest stages in Brassica oleracea L. vars. botrytis and italica. Planta 201:179-188.

Clifford HT 1987 Spikelet and floral morphology. In TR Soderstrom, KN Hilu, CS Campbell, ME Barkworth, eds. Grass systematics. Smithsonian Institution Press, Washington, D.C.

Cocucci AE, AM Anton 1988 The grass flower: suggestions on its origin and evolution. Flora 181:353-362.

Coen ES, S Doyle, JM Romero, R Elliot, R Magrath, R Carpenter 1991 Homeotic genes controlling flower development in Antirrhinum. Development (suppl 1):149-156.

Coen ES, EM Meyerowitz 1991 The war of the whorls: genetic interactions controlling flower development. Nature 353:31-37.

Cooke J, MA Nowak, M Boerljist, J Maynard Smith 1997 Evolutionary origins and maintenance of redundant gene expression during metazoan development. Trends Genet 13:360-364.

Crone W, EM Lord 1994 Floral organ initiation and development in wild-type Arabidopsis thaliana (Brassicaceae) and in the organ identity mutants apetala2-1 and agamous-1. Can J Bot 72:384-401.

Dahlgren RMT, HT Clifford, PF Yeo 1984 The families of the Monocotyledons. Springer, New York.

Davidson EH, G Ruvkin 1999 Themes from a NASA workshop on gene regulatory processes in development and evolution. J Exp Zool 285:104-115.

Davies B, A Di Rosa, T Eneva, H Saedler, H Sommer 1996 Alteration of tobacco floral organ identity by expression of combinations of Antirrhinum MADS-box genes. Plant J 10:663-677.

Dickinson WJ 1995 Molecules and morphology: where's the homology? Trends Genet 11:119-121.
Eames AJ 1961 Morphology of the angiosperms. McGraw-Hill, New York.

Endress PK 1986a Floral structure, systematics, and phylogeny in Trochodendrales. Ann Mo Bot Gard 73:297-324.

$1986 b$ Reproductive structures and phylogenetic significance of extant primitive angiosperms. Plant Syst Evol 152:1-28.

1987 Floral phyllotaxis and floral evolution. Bot Jahrb Syst 108:417-438.

$1994 a$ Diversity and evolutionary history of tropical flowers. Cambridge University Press, Cambridge.

- $1994 b$ Floral structure and evolution of primitive angiosperms: recent advances. Plant Syst Evol 192:79-97.

Force A, M Lynch, FB Pickett, A Amores, Y-L Yan, J Postlethwait 1999 Preservation of duplicate genes by complementary, degenerative mutations. Genetics 151:1531-1545.

Fryxell KJ 1996 The coevolution of gene family trees. Trends Genet 12:364-369.

Ganfornina MD, D Sanchez 1999 Generation of evolutionary novelty by functional shift. Bioessays 21:432-439.

Goto K, EM Meyerowitz 1994 Function and regulation of the Arabidopsis floral homeotic gene PISTILLATA. Genes Dev 8: 1548-1560.

Halfter U, N Ali, J Stockhaus, L Ren, N-H Chua 1994 Ectopic expression of a single homeotic gene, the Petunia gene green petal, is sufficient to convert sepals to petaloid organs. EMBO J 13: 1443-1449.

Hasebe M 1999 Evolution of reproductive organs in land plants. J Plant Res 112:463-474.

Heywood VH 1993 Flowering plants of the world. Oxford University Press, New York.

Hill JP, EM Lord 1989 Floral development in Arabidopsis thaliana: a comparison of the wild type and the homeotic pistillata mutant. Can J Bot 67:2922-2936.

Irish VF, EM Kramer 1998 Genetic and molecular analysis of angiosperm flower development. Adv Bot Res 28:197-230.

Jack T, LL Brockman, EM Meyerowitz 1992 The homeotic gene APETALA3 of Arabidopsis thaliana encodes a MADS box and is expressed in petals and stamens. Cell 68:683-697.

Jack T, GL Fox, EM Meyerowitz 1994 Arabidopsis homeotic gene APETALA3 ectopic expression: transcriptional and posttranscriptional regulation determine floral organ identity. Cell 76:703-716.

Jenik P, VF Irish 2000 Regulation of cell proliferation patterns by homeotic genes during Arabidopsis floral development. Development 127:1267-1276.

Kang H-G, J-S Jeon, S Lee, G An 1998 Identification of class B and class $\mathrm{C}$ floral organ identity genes from rice plants. Plant Mol Biol 38:1021-1029.

Kosuge K 1994 Petal evolution in Ranunculaceae. Plant Syst Evol 8(suppl):185-191.

Kramer EM 2000 Evolution of genetic mechanisms controlling petal and stamen development. PhD diss. Yale University, New Haven, Conn.

Kramer EM, RL Dorit, VF Irish 1998 Molecular evolution of genes controlling petal and stamen development: duplication and divergence within the APETALA3 and PISTILLATA MADS-box gene lineages. Genetics 149:765-783.

Kramer EM, VF Irish 1999 Evolution of genetic mechanisms controlling petal development. Nature 399:144-148.

Krizek BA, EM Meyerowitz 1996 The Arabidopsis homeotic genes APETALA3 and PISTILLATA are sufficient to provide the B class organ identity function. Development 122:11-22.

Ma H, C de Pamphilis 2000 The ABCs of floral evolution. Cell 101: $5-8$. 
Magallon S, PR Crane, PS Herendeen 1999 Phylogenetic pattern, diversity, and diversification of eudicots. Ann Mo Bot Gard 86: 297-372.

Meyerowitz EM, JL Bowman, LL Brockman, GN Drews, T Jack, LE Sieburth, D Weigel 1991 A genetic and molecular model for floral development in Arabidopsis thaliana. Development (suppl 1): 157-167.

Mouradov A, B Hamdorf, RD Teasdale, JT Kim, K-U Winter, G Theissen 1999 A DEF/GLO-like MADS-box gene from a gymnosperm: Pinus radiata contains an ortholog of angiosperm B class floral homeotic genes. Dev Genet 25:245-252.

Muller GB, GP Wagner 1996 Homology, Hox genes and developmental integration. Am Zool 36:4-13.

Ohno S 1970 Evolution by gene duplication. Springer, Heidelberg.

Qiu Y-L, J Lee, F Bernasconi-Quadroni, DE Soltis, PA Soltis, M Zanis, EA Zimmer, Z Chen, V Savolainen, MW Chase 1999 The earliest angiosperms: evidence from mitochondrial, plastid and nuclear genomes. Nature 402:404-407.

Schwarz-Sommer Z, I Hue, P Huijser, PJ Flor, R Hansen, F Tetens, W-E Lonnig, H Saedler, H Sommer 1992 Characterization of the Antirrbinum floral homeotic MADS-box gene deficiens: evidence for DNA binding and autoregulation of its persistent expression throughout flower development. EMBO J 11:251-263.

Smith GH 1926, 1928 Vascular anatomy of ranalian flowers. Bot Gaz 82:1-29, 85:152-177.

Soltis PS, DE Soltis, MW Chase 1999 Angiosperm phylogeny inferred from multiple genes as a tool for comparative biology. Nature 402: 402-403.

Sommer H, W Nacken, P Beltran, R Huijser, H Pape, R Hansen, P Flor, H Saedler, Z Schwarz-Sommer 1991 Properties of deficiens, a homeotic gene involved in the control of flower morphogenesis in Antirrhinum majus. Development (suppl 1):169-175.

Stewart WN, GW Rothwell 1993 Paleobotany and the evolution of plants. $2 \mathrm{~d}$ ed. Cambridge University Press, Cambridge.
Sun G, D Dilcher, S Zheng, Z Zhou 1998 In search of the first flower: a Jurassic angiosperm, Archaefructus, from northeast China. Science 282:1692-1695.

Sundstrom J, A Carlsbecker, M Svenson, ME Svensson, P Engstrom 1999 MADS-box genes active in developing pollen cones of Norway Spruce are homologous to the B-class floral homeotic genes in angiosperms. Dev Genet 25:253-266.

Swofford D 1993 Phylogenetic analysis using parsimony. Illinois Natural History Survey, Champaign.

Takhtajan A 1991 Evolutionary trends in flowering plants. Columbia University Press, New York.

Theissen G, A Becker, A Di Rosa, A Kanno, JT Kim, T Munster, K-U Winter, H Saedler 2000 A short history of MADS-box genes in plants. Plant Mol Biol 42:115-149.

Trobner W, L Ramirez, P Motte, I Hue, P Huijser, WE Lonnig, H Saedler, H Sommer, Z Schwarz-Sommer 1992 Globosa-a homeotic gene which interacts with deficiens in the control of Antirrhinum floral organogenesis. Eur Mol Biol Organ J 11:4693-4704.

Tucker SC 1960 Ontogeny of the floral apex of Michelia fuscata. Am J Bot 47:266-277.

van Tunen AJ, W Eikelboom, GC Angenent 1993 Floral organogenesis in Tulipa. Flowering News 16:33-37.

Winter K-U, A Becker, T Munster, JT Kim, H Saedler, G Theissen 1999 MADS-box genes reveal that gnetophytes are more closely related to conifers than to flowering plants. Proc Natl Acad Sci USA 96:7342-7347.

Wray GA, E Abouheif 1998 When is homology not homology? Curr Opin Genet Dev 8:675-680.

Zachgo S, E de Andrade Silva, P Motte, W Trobner, H Saedler, Z Schwarz-Sommer 1995 Functional analysis of the Antirrhinum floral homeotic Deficiens gene in vivo and in vitro by using a temperature-sensitive mutant. Development 121:2861-2875. 